\title{
Matthew Gibbons
}

\section{Government Expenditure in New Zealand since 1935: a preliminary reassessment}

Introduction

The optimal size of government is an important political and economic issue. However, because no long-term government expenditure series has official standing, New Zealand is often a missing case in comparative studies of government expenditure (Castles, 1998). Although government expenditure data is available from 1972 on Treasury's website (New Zealand Treasury, 2016), the most widely used data before 1972 is a 'consolidated' long-term data series, on Statistics New Zealand's website, which uses data from a number of sources and is published with strong disclaimers.

This article draws together alternative data, primarily from published official sources, to show that better quality data is often available from different printed sources. It discusses why the alternative data is more accurate and consistent,

and considers what the data shows about changes in the role of the state in New Zealand.

The article first defines government expenditure, and considers other ways in which governments affect people's

Matthew Gibbons is a graduate of the Politics Department at the University of Waikato. This article is based on his PhD thesis, which was funded by a Waikato postgraduate scholarship. behaviour and purchasing power. The best available expenditure series are then outlined, and changes in government expenditure over time examined. The low reporting of tax expenditures in New Zealand, compared to other countries, is discussed. Finally, the weaknesses of New Zealand's most widely used expenditure data set are considered.

\section{Defining government expenditure}

Government expenditure is frequently defined as economic activity that is subject to public expenditure budgetary processes. Governments can directly provide goods and services, or fund their provision. Some types of government expenditure, such as pensions, primarily involve people buying private goods and services of their choice, rather than public sector economic activity (Wanna, Kelly and Forster, 2000, pp.7-8). Indeed, transfers and interest expenditure are not part of gross domestic product (GDP). Nevertheless, it is common practice of 
many economists, but not statisticians, to report government expenditure as a percentage of GDP (Gemmell, 1993, pp.23, 6-8; New Zealand Planning Council, 1979, p.33).

GDP is the market value of all final goods and services produced within a country. It excludes intermediate consumption, and instead measures value added by firms (Briggs, 2003, 2007, 2016, p.34). GDP also excludes home production and the level of environmental degradation, but includes imputed income on owner-occupied housing (Fiorramonti, 2013, pp.12-15, 56, 110). Treasury's Living Standards Framework recognised that there are a broad range of material and non-material determinants of living standards (Gleisner, LlewellynFowler and McAlister, 2011).

As well as directly purchasing goods and services and paying transfers, governments can also affect people's behaviour, the distribution of income and economic outcomes through taxes, regulations, procurement policies, asset sales and expenditure mandates (Hofferbert and Budge, 1996, p.26). Some countries, such as Australia, Singapore and the United States, have particularly high mandated expenditures. For example, Australian employers and employees are required to make pensions scheme contributions, while accident cover is through employer-funded insurance. There is also a growing literature on tax expenditures. Tax expenditures are loopholes or breaks, such as deductions, preferential rates, deferrals or exclusion of some types of income from tax (Howard, 1997, p.4; OECD, 2010, p.13).

\section{New Zealand expenditure data}

State expenditure account (Treasury,

1935-38)

During the 1920s the Crown's accounts were reorganised on 'commercial lines' (Forbes, 1931, p.10) that followed scientific management thinking, and separately identified the costs of activities (Ashwin, 1935). From 1930 a consolidated state balance sheet was published, and from 1935 Treasury added an accrual state income and expenditure account. By bringing together expenditure from all departmental accounts, this provided the first official whole-of-government expenditure statistics. Although this account excluded fixed asset purchases, it included capital charges (New Zealand Treasury, 1935, p.88).

The state expenditure account series was published for four years, and then never resumed after being 'discontinued until after the conclusion of the war' (Statistics Department, 1941, p.494). Indeed, after the Second World War there was a further decrease in the resources committed to reporting departments' finances using commercial practices.

National accounts (Statistics Department, refined by the Planning Council, 1939, 1944, 1950-79)

For 1939 and 1944, however, there are 'preliminary estimates' of government expenditure, calculated on the new United Nations and government-favoured capital formation (public investment) and transfers and other current expenditure such as interest and subsidies. Hospital board expenditure was also reclassified as central government expenditure for the entire period (New Zealand Planning Council, 1979, pp.8, 26-7).

\section{Financial net expenditure (Treasury, 1963-} 72 (retrofit) and 1973-94)

By the early 1960s Treasury was producing a summary budget table, showing income and expenditure for all government accounts, and in 1967 received permission to publish this table (McKinlay, 1983). After further refinement, Treasury published a ten-year retrospective functional series that included eight broad categories of expenditure and 18 more detailed categories (New Zealand Treasury, 1973). Treasury continued its financial net expenditure series until 1994, and data from 1972 to 1993, with a slight

\section{... governments can ... affect people's behaviour, the distribution of income and economic outcomes through taxes, regulations, procurement policies, asset sales and expenditure mandates ...}

national accounts basis (Statistics Department, 1950, p.604). From 1947 this series became permanent, and continued on a consistent basis for key expenditure classifications until 1979. Although government departments operated on a cash basis, trading departments, such as the post office, used private sector accounting methods. This series was net, and included capital formation by state trading enterprises (New Zealand Planning Council, 1979, p.8).

The national accounts data reported the cost of government-provided goods and services separately from cash transfers such as pensions, benefits and interest payments (Statistics Department, 1953, p.595). When the Planning Council published data from this series from 1950, however, central government expenditure included current expenditure on goods and services (public consumption), gross downward adjustment in early years and a substantial upward adjustment from the late 1980s to allow for net lending less repayments, is on Treasury's website (New Zealand Treasury, 2016). This series has been included in this article from 1963.

Financial net expenditure was based on government appropriations, after allowing for departmental receipts (Shand, 1979, p.353), and included the consolidated fund, the loans account and the national roads fund (Preston, 1980, pp.41-2). Net expenditure was a financing concept which showed the level of funds that needed to be raised (Shand, 1979, p.354). Although cash-based, departments sometimes spread capital purchases across years (Preston, 1980, pp.57, 61), while governments transferred money into war accounts to fund military expenditure events for which final costs were uncertain. 
Figure 1: Government expenditure as a percent of GDP

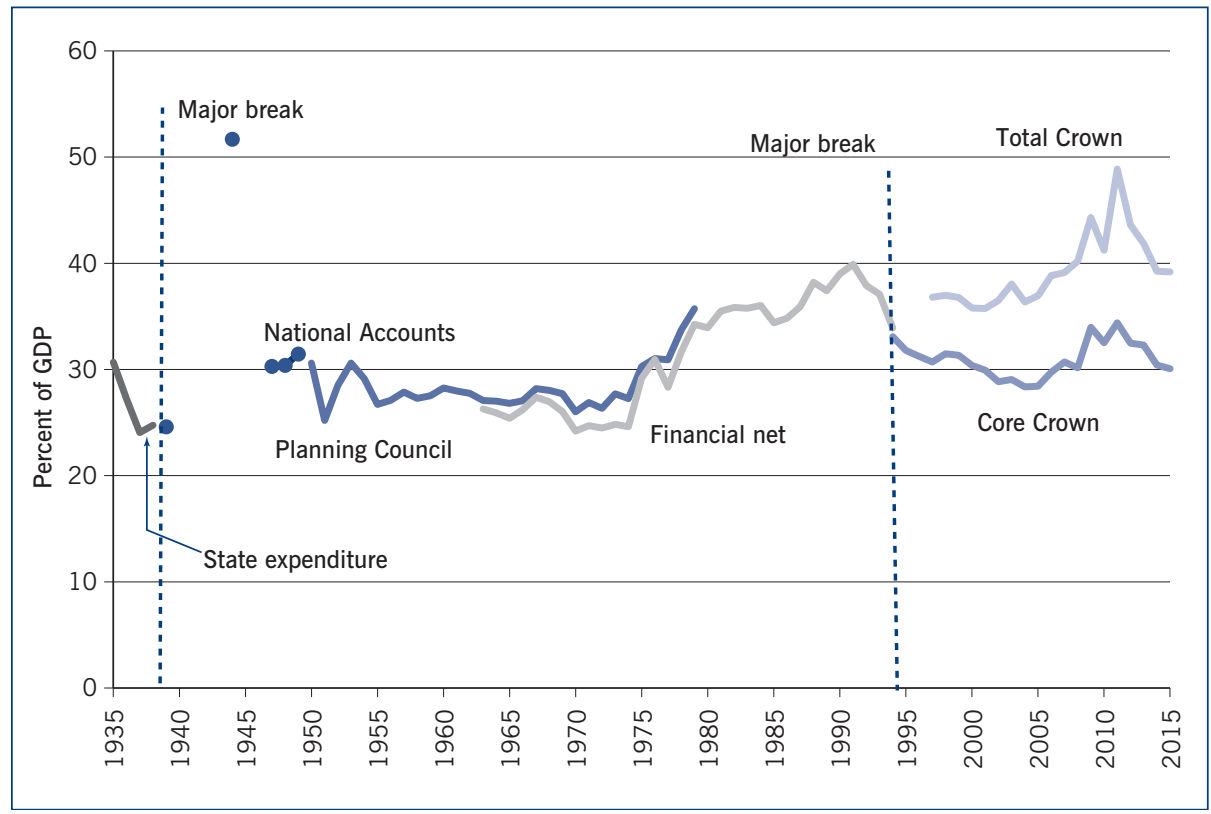

Gibbons (2000) worked out how some of the functional categories were calculated, and extended them back to 1950. Total financial net expenditure is often almost identical to total expenditure in the Statistics Department's national accounts series (Tan, 1981). Splicing these two series together provides information on changes in total government expenditure for 1939 and 1944 and for 1947-94.

Some changes occurred to financial net expenditure over time. Although some changes are difficult to quantify, the 1986 Budget noted that changes would increase net expenditure by approximately $4.3 \%$, 'without adding to the government's claim on total resources' (New Zealand Treasury, 1986, p.33). Changes include categorising Family Support tax rebates as expenditure, adding GST onto expenditure by government departments, not deducting import licensing revenue from Trade and Industry expenditure, and, for equity and administrative reasons, grossing up most remaining untaxed benefits and making them subject to income taxation (New Zealand Treasury, 1986, p.33).

Core Crown expenses (Treasury, 1994-) and total Crown expenses (Treasury, 1997-)

The 1994 Budget was the first prepared under New Zealand generally agreed accounting practice (GAAP) and switched from a predominantly cash-based expenditure system to an accrual system. Capital expenditure by government departments was no longer included, and, although depreciation on physical assets was added, this was not a close equivalent. While capital charges were now appropriated, they were eliminated on consolidation. Furthermore, whereas since 1939 functional classifications had shown net expenditure, core Crown expenditure was gross. In addition, the functional classification used changed to classification of functions of government (COFOG) used by the International Monetary Fund, while expenses now included the Reserve Bank (New Zealand Treasury, 1994, pp.170-5). In addition, after 1994 GST was excluded from departmental and non-departmental output classes. These changes created a 'fundamental break' in the fiscal time series (ibid., pp.33, 75; New Zealand Treasury, 2008, p.7).

From 1997 government expenditure statistics used international financial reporting standards. However, by subtracting net foreign exchange gains and losses from the 1994-96 data it is possible to control for the major change (New Zealand Treasury, 2008). The switch to public benefit entity standards (backdated to 2005) has fractionally reduced government expenditure over this period. Furthermore, from 1997 statistics for total Crown expenses, which include all expenses of Crown entities and state-owned enterprises, thus including ACC and commercially operated businesses, such as electricity companies, were reported.

\section{Changes in government expenditure in New Zealand}

The state expenditure account provides the first four years of data in Figure 1, with the first year of data preceding the election of New Zealand's first Labour government in late 1935. Government expenditure fell between 1935 and 1938 as a proportion of GDP. This largely reflected a buoyant economy; in inflation-adjusted terms there was considerable growth in government expenditure. Furthermore, the first Labour government used savings on relief payments, which during the Depression had become New Zealand's biggest welfare programme, to fund other social services (Gibbons, 2001, pp.5-6). Because total expenditure by commercial enterprises was included, this series has some conceptual similarities with Treasury's current total Crown series.

The national accounts data show that government expenditure declined from a peak in 1944, when New Zealand's war effort was greatest, although it was still higher than the pre-war level. Nevertheless, government expenditure was slightly lower in the 1960s under National than under Labour in the late 1940s. Internationally this was unusual (Castles, 1998, p.100), and may reflect National using tax expenditures rather than direct expenditure. For instance, National made private health insurance tax deductible, reduced taxes on land and on selected goods purchased by voters it was targeting, and used the tax system to encourage particular types of investments (Goldsmith, 2008, p.236). National also preferred to deliver housing and farming assistance through discounted asset sales and low-cost mortgages, rather than as reported expenditure (Auditor-General, 1951, p.37).

During the second half of the 1970s government expenditure increased from $25 \%$ of GDP in 1974 to $34 \%$ in 1980 , fuelling concern that public sector overload was occurring (New Zealand Planning Council, 1979). Government expenditure peaked at $38 \%$ of GDP in 
1991, before declining. Indeed, core Crown expenditure fell from $34.4 \%$ of GDP in 1994 to $29.5 \%$ of GDP in 2004 , before slowly increasing to a peak of $35.1 \%$ in 2011. Since then it has decreased to $30.1 \%$ of GDP in 2015, although, due to operating balance deficits and other cash outflows, the government's debt has substantially increased since 2009. In Figure 1, total Crown expenditure has also been included as a proportion of GDP. However, some of this expenditure is not a component of GDP, and some other expenditure is transfers that individuals personally spend. Indeed, the government sector probably accounts for between a fifth and a quarter of the economy (Easton, 2007).

A functional breakdown of many areas of government expenditure is available. The results (Figures 2-11) show defence expenditure trending downwards after peaking during the Korean War. However, law and order expenditure has sharply increased, reversing the trend of the first half of the century (Gibbons, 2001), as reported crime rates and concern about crime have grown. Although there is usually a strong statistical relationship between political parties' manifesto emphases on particular topics and equivalent subsequent government expenditure trends, this relationship is particularly strong for law and order (Gibbons, 2000, p.289). Health and education expenditure have both increased, although evidence of retrenchment by National during the early 1980s is visible.

There was a sharp increase in expenditure on both land use and other industrial services and energy by the third National government, which was reversed after 1984 by Labour (Rudd, 1991, p.155). For instance, appropriated land use expenditure was $2.7 \%$ of GDP in 1984 , compared to less than $1 \%$ during the 1960s. Similarly, economic and industrial services expenditure was often a percentage point of GDP higher in the early 1980s than during the 1960s. Payments for past major industrial projects and for producer board refinancing (not graphed here) were significant contributors to government expenditure between 1987 and 1990, with costs peaking at $5.8 \%$ of GDP in 1987 , although, in accordance with usual practice, these have been excluded from total government expenditure. Economic development expenditure has substantially increased since 1997, although not to the levels of the early 1980s. Treasury does not currently report total primary sector expenditure. However, irrigation subsidies have increased under the current government, despite concerns about their economic worth (New Zealand Treasury, 2010). Furthermore, the terms under which high country farmland becomes freehold have been generous to farmers (Brower, 2008).

The government's interest costs (Figure 9) increased sharply from 2.2\% of GDP in 1975 to $7.7 \%$ in 1988 . However, some interest payments reflected inflation reducing the value of borrowed money, although the government's debt also increased in real terms. Interest costs then fell as assets were sold, nominal interest rates declined, and there were periods of
Figure 2: Defence expenditure as a \% of GDP

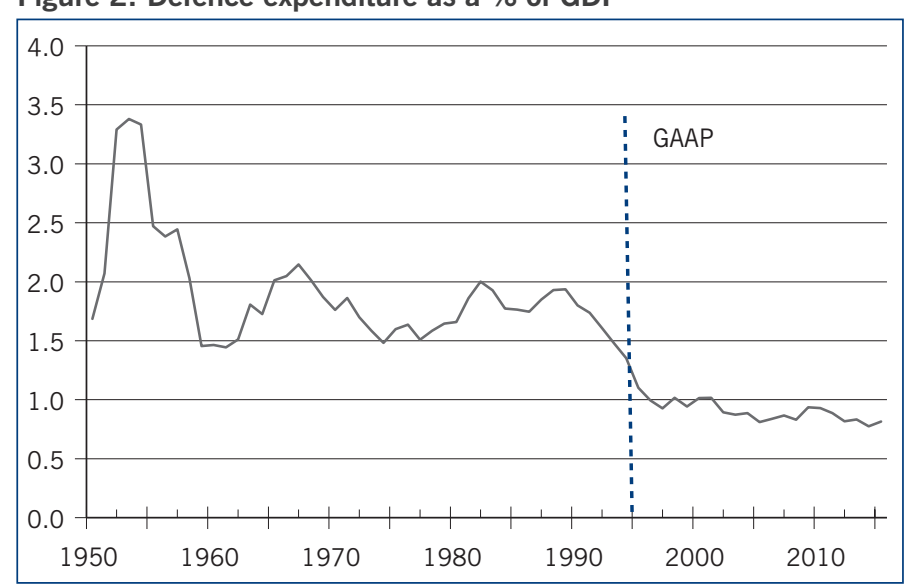

Figure 4: Health expenditure as a \% of GDP

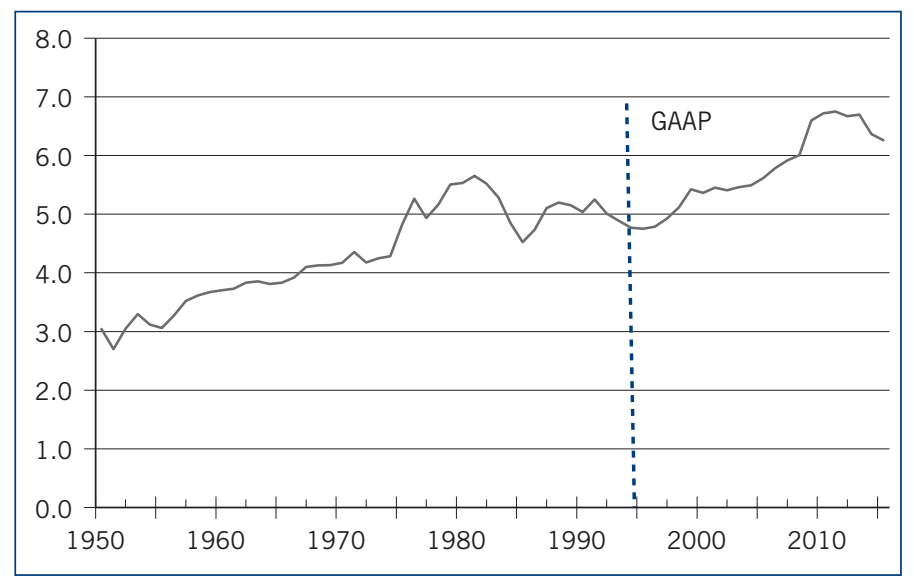

Figure 3: Law and order expenditure as a \% of GDP

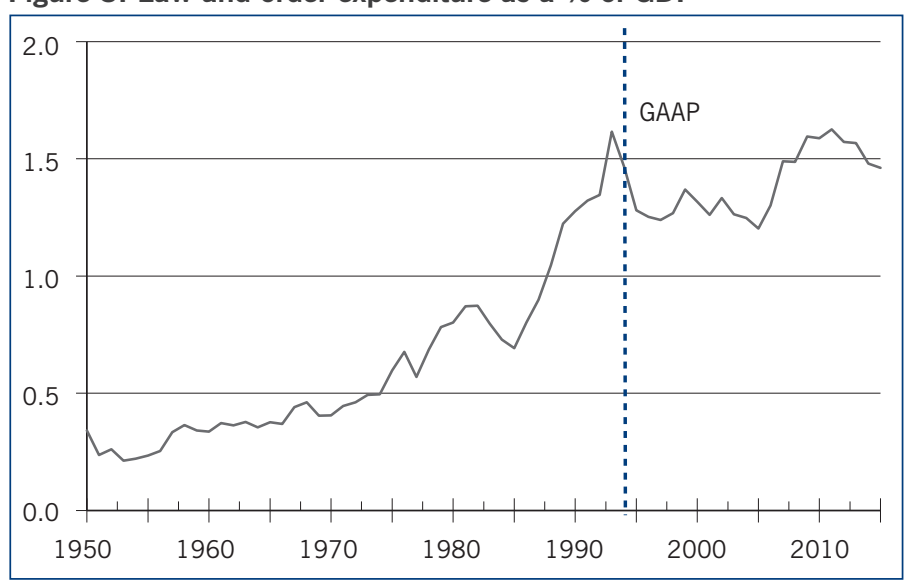

Figure 5: Education expenditure as a \% of GDP

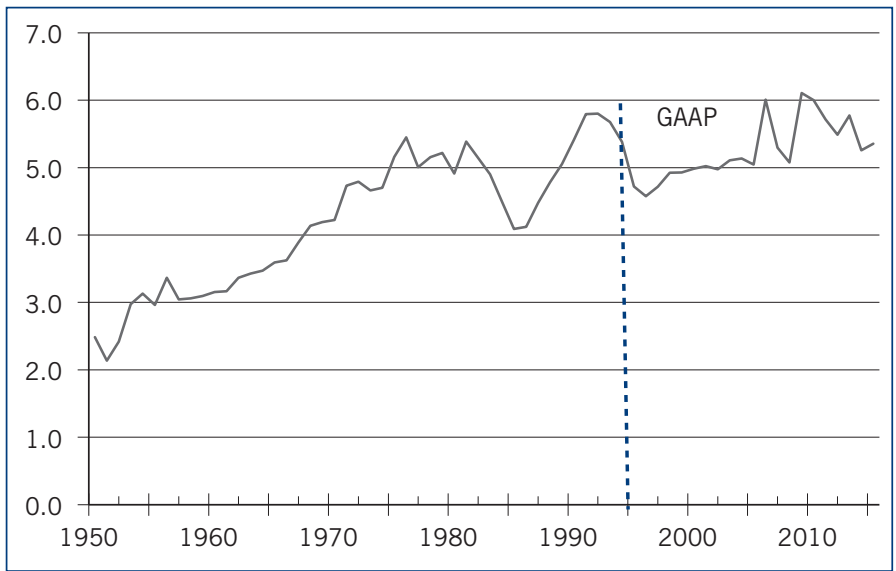


Figure 6: Transport and communications expenditure as a \% of GDP

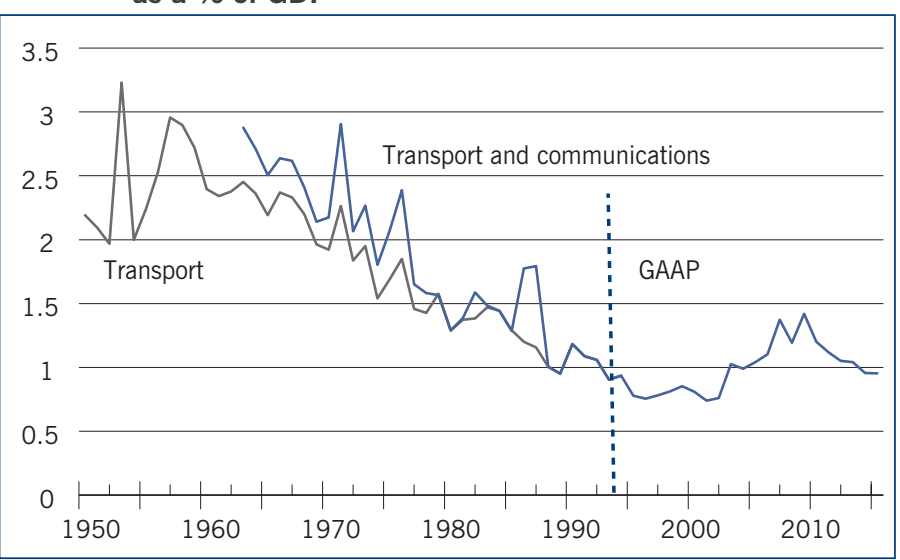

Figure 8: Economic and industrial services as a \% of GDP

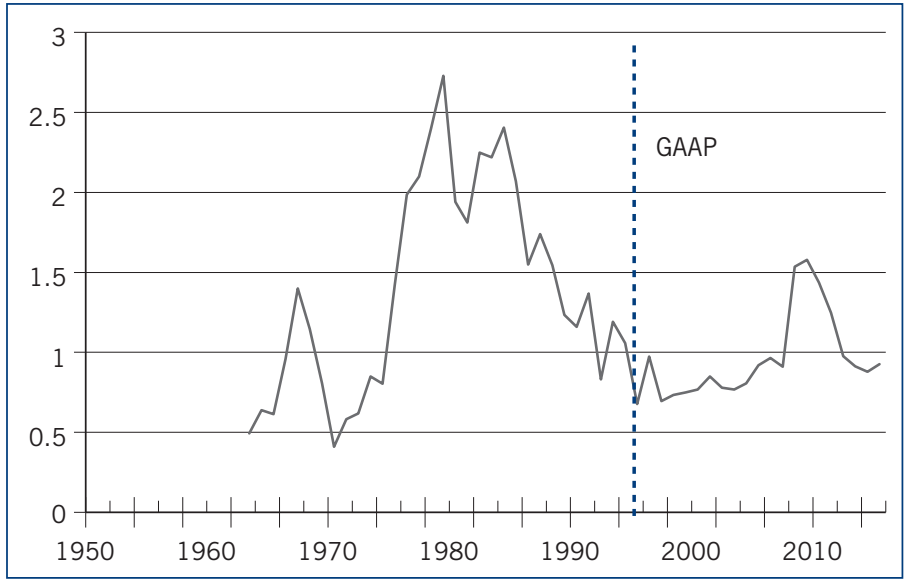

Figure 10: Net lending less repayments as a \% of GDP

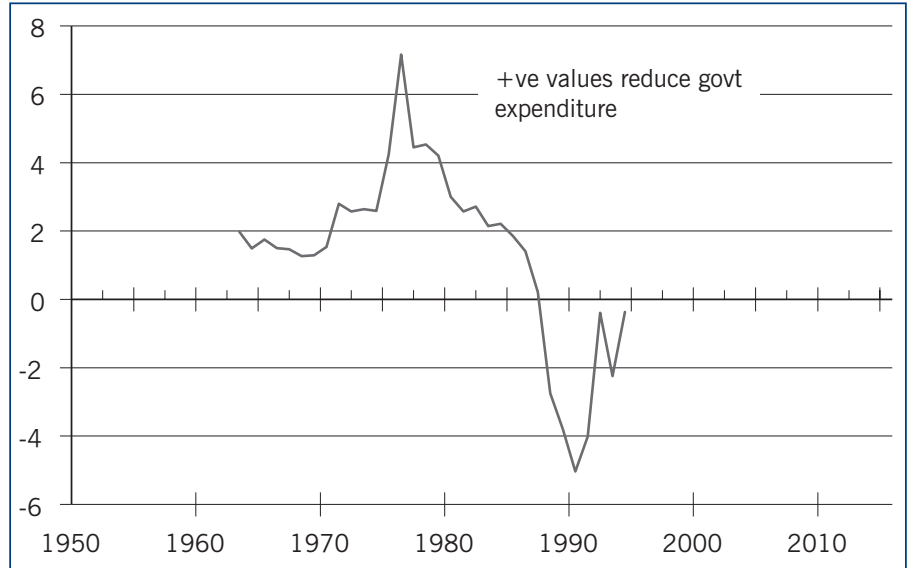

Figure 7: Land use expenditure as a \% of GDP

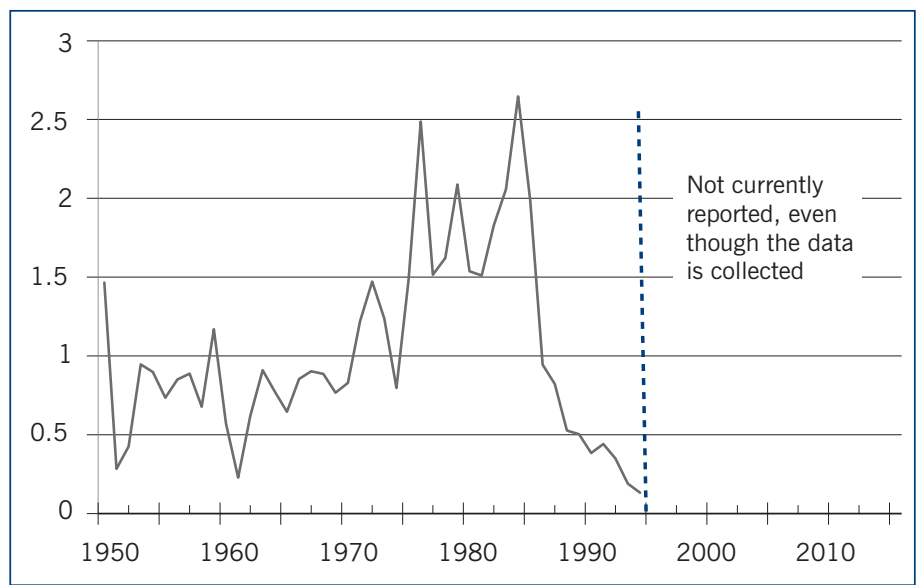

Figure 9: Government interest expenditure as a \% of GDP

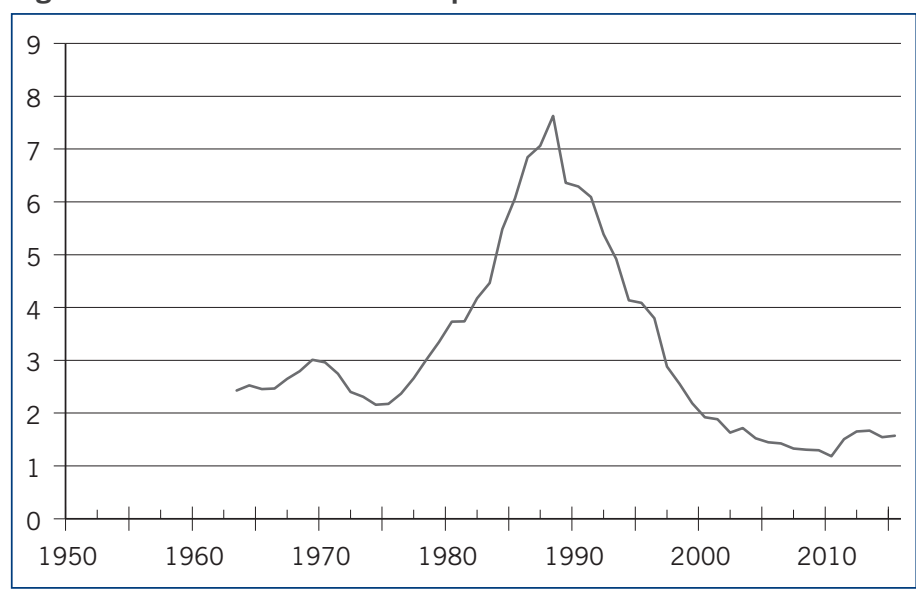

Figure 11: Social security and welfare expenditure as a \% of GDP

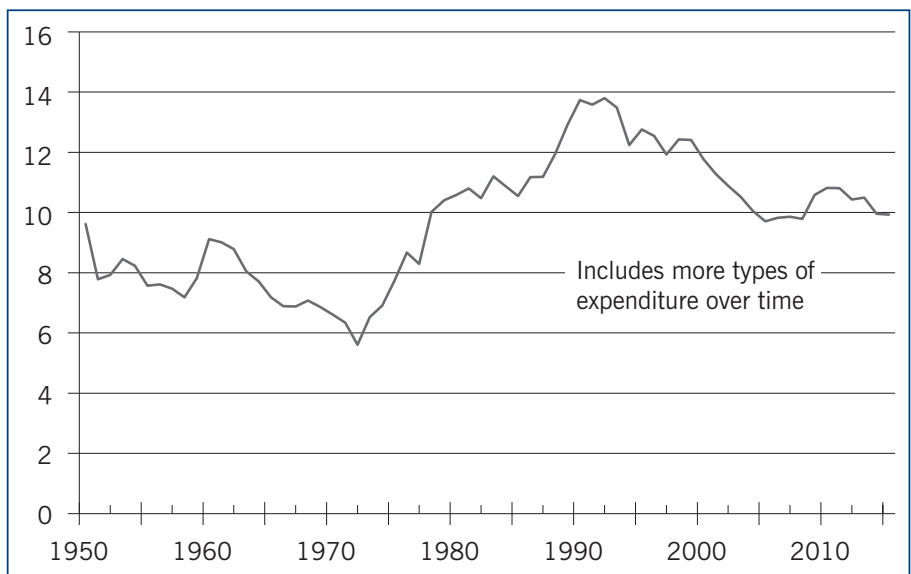

fiscal surpluses. Since Treasury now subtracts net lending (Figure 10) from government expenditure, this reduces total government expenditure up to 1988 , and increases net expenditure substantially for the next few years (Rudd, 1991, p.147).

From the mid-1970s there was also growth in expenditure on social security and welfare. Figure 12 shows that superannuation expenditure increased from about 3\% of GDP in the early 1970 s to almost $7 \%$ by 1980 , and accounted for almost half of the $9 \%$ increase in government expenditure as a proportion of GDP. ${ }^{1}$ However, Figures 11 and 12 do not show how some of the cost of ending means-testing for those aged between 60 and 65 and of higher pension rates was recovered by making a formerly meanstested pension subject to income taxation (Preston, 2008, p.14) at a time when marginal tax rates for high-income earners were high. Due to an increase in the age of eligibility and demographic changes, superannuation spending is now lower than in the early 1990s, but is higher than before the mid-1970s. Superannuitants have also benefitted from lower marginal tax rates and the end of mandatory retirement rules, with the latter change boosting both their labour market participation and the tax base.

During the 1970s and 1980s expenditure on benefits for single parents increased. In addition, payments to wage earners also steadily increased during the 1970s and 1980s, particularly after 1986, due to increasing unemployment, and peaked at $2.8 \%$ of GDP in 1994. In contrast, family support payments declined over time, after peaking at $2.6 \%$ of GDP in 1961, and were 1.4\% of GDP in 
2012. Indeed, the universal family benefit was abolished in 1991 in favour of more targeted assistance, with $89 \%$ of Working for Families expenditure in 2010 going to families in the lower half of the income distribution after equivalising for family size (Aziz et al., 2012, p.33).

More expenditure on families has been recorded over time, with the decision in 1973 to increase the family benefit but abolish a long-standing tax exemption for families with children increasing appropriated family support expenditure (Figure 12), without significantly changing the income distribution (New Zealand Planning Council, 1979, p.10). During the 1980s tax credits specifically for low-income families, which had grown since the late 1970s, also became appropriated expenditure. Then during the 1990s formerly unquantified incomerelated rent subsidies to state housing tenants became funded: first in 1991 through an expanded accommodation supplement, and then after 1999 by the reintroduction of income related rents for those with incomes below the level of New Zealand superannuation. Furthermore, although the net fiscal expenditure series allocated contributory government employee pensions to functional expenditure areas, under COFOG this constitutes social security expenditure. Including consumer subsidies would considerably increase welfare expenditure during the 1950s, when these were sometimes over $2.5 \%$ of GDP, and to a lesser extent also during the 1960s and some years in the 1970s (ibid., pp.27-30; Rose, 2014, p.12).

\section{Tax expenditures and international comparisons}

International comparisons of government expenditure are difficult, partly because some countries make heavy use of tax expenditures and mandatory private expenditures to achieve policy goals (OECD, 2011, p.64). For instance, tax expenditures for education, housing and health care are equivalent to one-fifth of appropriated government expenditure in Australia, and amount to almost half of appropriated welfare expenditure in the United States (Howard, 1997, pp.18, 27; Stebbing and Spies-Butcher, 2010, pp.593-
Figure 12: Expenditure on different types of transfers as a \% of GDP, 1950-2012

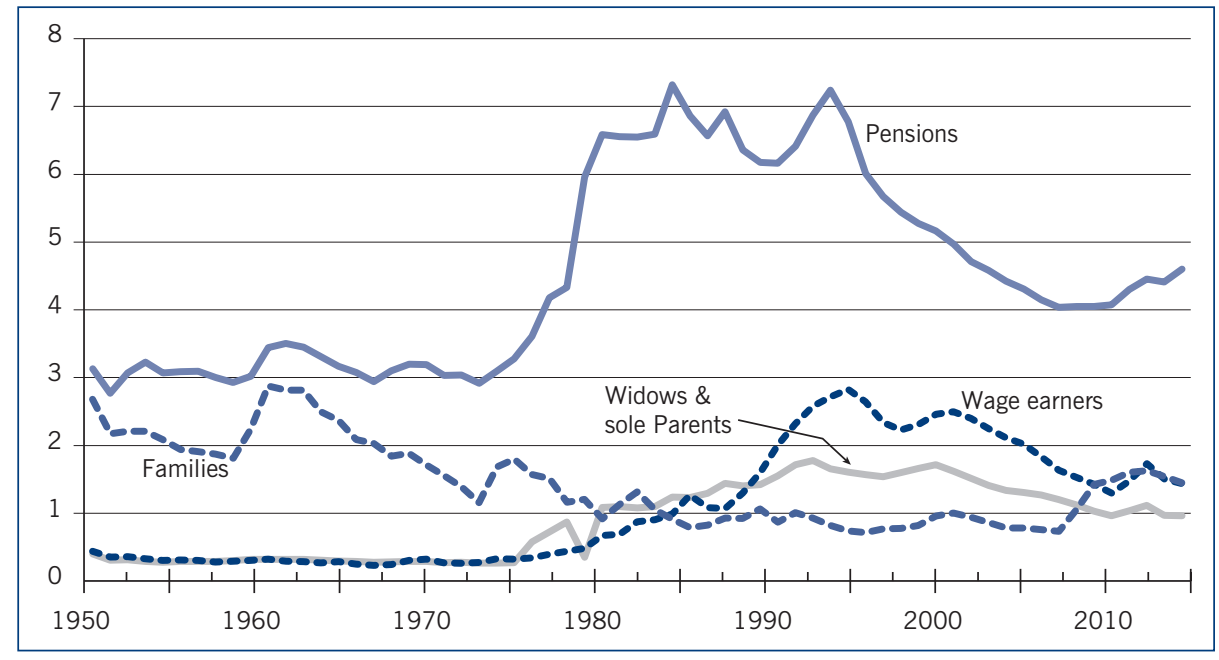

5, 597). Tax incentives and breaks are often popular with voters because they are frequently seen as tax cuts rather than increases in expenditure, and there is less oversight and targeting of them. They tend to benefit higher-income earners most (Burman, Geissler and Toder, 2008; Faricy, 2011), although in the United States the earned income tax credit for low-income families with dependent children is a tax expenditure. Despite the Charter of Budget Honesty (1998), there has been a political consensus on keeping reported government expenditure low in Australia (Wanna, Kelly and Forster, 2000, p.282). Differences in welfare spending also shrink when the decision by the United States and Australia to not tax cash transfers or apply sales tax to perceived necessities and merit goods is considered (Howard, 2007, pp.14-16).

New Zealand's first tax expenditures statement was in the 1984 Budget, and listed 112 tax concessions and expenditures (New Zealand Treasury, 1984, pp.20-30). Some tax expenditures were subsequently abolished, and others became appropriated expenditure. As a 'first step' towards improving its financial reporting, Treasury reintroduced a short tax expenditures statement, which quantified nine tax expenditures, in 2010. The biggest items were income tax deductions on charitable donations ( $\$ 235$ million) and the independent earner credit (\$212 million) for middle-income workers who do not receive other tax credits or cash benefits and after the 2009 taxation changes paid more sales tax but did not benefit from the top income tax rate reduction. However, Treasury noted that its list was incomplete (New Zealand Treasury, 2014, p.3).

Indeed, New Zealand's tax system has features that elsewhere are quantified tax expenditures. For instance, tax deductions on mortgage interest on owner-occupied property are recorded as a tax expenditure in the United States (Howard, 1997, pp.21-2), but the reduction in tax revenue from $\$ 650$ million per year in losses on residential property investments is not recorded in New Zealand's tax expenditures statement. Rental property tax arrangements in New Zealand enable providers to build retirement wealth while sometimes reducing the cost of renting (Coleman, 2009; King, 2014). However, a disadvantage of not annually recording and monitoring these expenditures is that providers do not face the contestability, conditionality, and requirement to efficiently provide quality services, with annual improvements in the quality and quantity of services, which occur for other service providers. For instance, the interest expense deduction could be restricted to the capital cost (excluding land) of new high-density housing, and not available to reduce other taxable income.

Similarly, the ability by farmers to lower their taxes through income averaging is a quantified tax expenditure in Australia (Australian Treasury, 2014, p.66) but not in New Zealand. Furthermore, the loss of revenue from not taxing capital gains on owner-occupied housing is reported in Australia. In addition, the decision to exclude all imputed income on housing from income 
Figure 13: Government expenditure as a percentage of GDP since 1870 in NZIER's Looking at the numbers

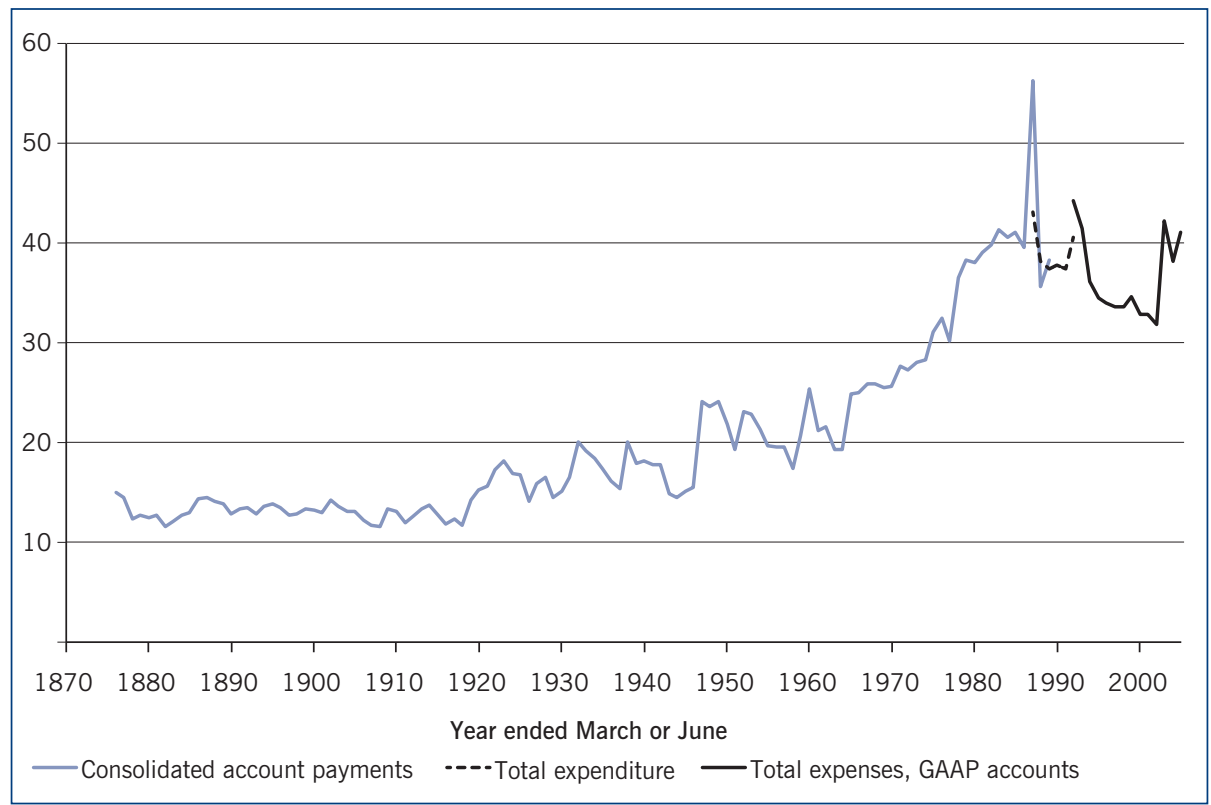

Figure 14: Government expenditure as a percent of GDP with Consolidated series added

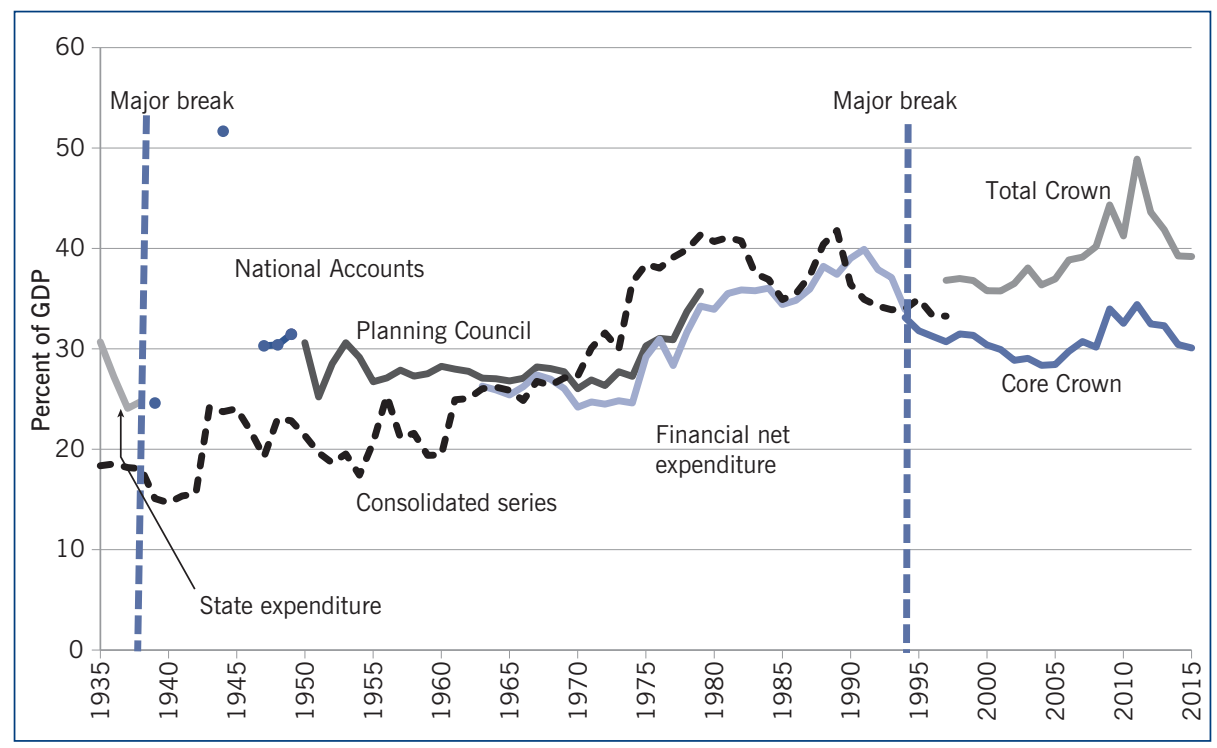

taxes has been criticised in Australia (Jones, 1980, p.178; Stebbing and SpiesButcher, 2010, p.593). It has also been suggested that these sources of income should be taxed in New Zealand so that other taxes can be reduced, and to increase investment in productive activities (Financial Services Council, 2013, pp.5, 22). Indeed, the OECD has recommended that New Zealand implement a comprehensive capital gains tax to promote equity and economic efficiency (OECD, 2013, pp.3, 22). Political pressures have protected employee car parking privileges from fringe benefit tax (Shuttleworth, 2013), although this could reduce traffic congestion. Small business owners have also benefitted from tax changes that facilitate counting personal consumption as a business expense. It is therefore important to consider not just the level of recorded government expenditure, but also unrecorded tax breaks and policies that facilitate high and rising prices for assets such as residential property.

\section{Alternative data sets}

The total expenditure series in Figure 1 come from consolidated functional expenditure series based on Treasury or Statistics New Zealand publications. However, the most-used long-term government expenditure graph for New
Zealand uses a consolidated expenditure series that is shown in Figure 13. Slightly different versions of this graph have appeared in a New Zealand Institute of Economic Research economic history text (Briggs, 2003, 2007, 2016), two articles in this journal (Gemmell and Gill, 2016, p.4; Rea, 2009, p.62), and a Productivity Taskforce report (2025 Taskforce, 2009, p.82). However, a Treasury report on governments and economic growth partly used data collected and created by the author of this article (Cook, Schousboe and Law, 2011, p.27). Treasury's fiscal updates have sometimes included graphs from the 1950s onwards for functional expenditure that include series from the current author's $\mathrm{PhD}$ thesis (New Zealand Treasury, 2006, pp.57, 74, 95, 96), but have not included long-term total government expenditure.

Overlapping the series reveals considerable differences (Figure 14). In particular, the consolidated series shows continual growth in government expenditure between the early 1950s and the early 1980s, supporting age-ofdemocracy theories of growth in government (Olson, 1982, pp.41, 132-3). In contrast, the more consistent Planning Council and financial net expenditure series show no increase until the mid1970s.

These differences partly occur because the consolidated series has absorbed other government accounts over time (Committee on the Simplification of the Public Accounts, 1962). In particular, in 1964 the consolidated fund, social security fund and the gas industry account merged to form the consolidated revenue account, boosting government expenditure by $13 \%$. Similarly, after reductions in scope during the 1970s, the abolition of the works and trading account in 1978 further increased consolidated account expenditure. In addition, consolidated series data were reported on a gross basis from the early 1950s, whereas the functional series were net until 1994.

The limitations of the consolidated series raise the question of why it has been so widely used to illustrate changes in government expenditure. Historic expenditure data from the consolidated fund and consolidated revenue account 
has sometimes been printed in Yearbook appendices with the warning that 'The figures shown ... are not on a comparable basis' (Statistics Department, 1980, p.934). The consolidated expenditure data has been reprinted with similar disclaimers in historical statistics texts (Bloomfield, 1984, p.335; Thorns and Sedwick, 1997, p.103).

The consolidated data was included in an internal Treasury data set in the early 2000s, and Treasury staff added expenditure as a percentage of GDP and a graph similar to Figure 13. Later this data was published on a long-term data series website hosted by Statistics New Zealand. This website carries strong disclaimers encouraging users to check the statistics themselves, and the expenditure sheet notes that the data is 'not strictly consistent' (New Zealand Treasury, 2004). However, the series has met the desire of researchers to have a graph showing longterm expenditure, although users have usually repeated Treasury's warning and asked Treasury staff if better data are available.

Caution remains necessary when considering other government expenditure statistics. For instance, in published statistics on per student education costs early childhood and tertiary education appears relatively expensive compared to the compulsory sector. However, because the Ministry of Education is responsible for school property, the capital charge on school property is eliminated on consolidation. Differences in per student government expenditure on compulsory education and on early childhood and tertiary education become much smaller when all property funding is considered on an equivalent basis. Furthermore, student allowance and loan costs are included in tertiary education expenditure, but family tax credits are not included in other types of education expenditure.

\section{Conclusion}

This article has shown that the best available published functional government expenditure statistics present a different picture of growth in government since 1935 to the consolidated expenditure series used in other publications. In particular, the functional series show that government expenditure was relatively stable between the late 1940s and the mid-1970s, although expenditure increased thereafter. This increase was largely due to higher social security expenditure on pensions by the third National government, although some of the increase was recovered by making formerly means-tested pensions subject to income tax. Interest costs for the government also steadily increased from the late 1970s, while expenditure by National on land use and on economic services was high from the late 1970s to mid-1980s. During the 1980s, expenditure on means-tested benefits, but not on assistance to families, also grew. New Zealand government expenditure has fallen as a percentage of GDP since 1991, with pensions expenditure falling sharply due to a higher eligibility age and demographic changes. Interest costs and expenditure on means-tested benefits also declined from the early 1990s.

The statistics in this article exclude tax expenditures, which are important in other countries and under-reported in New Zealand. However, the functional data used in this article are better than the Consolidated expenditure series used by several other publications, since they include a wider range of government activities and are more consistent over time.

\footnotetext{
1 Pensions expenditure includes the old age pension and superannuation, but not civil servants' pensions. Wage earne benefits are the unemployment, sickness and invalid benefits. Widows and sole parent benefits include the DPB and orphans' benefits. Family support includes the family benefit and, since the 1980s, appropriated expenditure on family care, family support, Working for Families and paid parental leave. Accident insurance is not core Crown expenditure, while housing and veterans' pensions are excluded due to definitional changes. Sources include the long-term data series and Appendices to the Journals of the House of Representatives.
}

\section{References}

2025 Taskforce (2009) Answering the \$64,000 Question, Wellington: New Zealand Government

Ashwin, B.C. (1935) Practical Problems in Public Finance, Wellington: Commerce Society, Victoria University College

Auditor-General (1951) 'Report of the Controller and Auditor-General', Appendices to the Journals of the House of Representatives, B-1, part 2

Australian Treasury (2014) Tax Expenditures Statement 2013, Canberra: Commonwealth of Australia

Aziz, O., M. Gibbons, C. Ball and E. Gorman (2012) 'The effect on household income of government taxation and expenditure in 1988 , 1998, 2007 and 2010', Policy Quarterly, 8 (1), pp.29-38

Bloomfield, G.T. (1984) New Zealand: a handbook of historical statistics, Boston: G.K. Hall

Briggs, P. (2003, 2007, 2016) Looking at the Numbers: a view of New Zealand's economic history, Wellington: NZIER

Brower, A. (2008) Who Owns the High Country?, Nelson: Craig Potton

Burman, L.E., C. Geissler and E.J. Toder (2008) 'How big are total individual income tax expenditures, and who benefits from them?', American Economic Review, 98 (2), pp.79-83, doi: $10.2307 / 29729999$
Castles, F. (1998) Comparative Public Policy: patterns of post-war transformation, Cheltenham: Edward Elgar

Coleman, A. (2009) The Long Term Effects of Capital Gains Taxes in New Zealand, Wellington: Motu

Committee on the Simplification of the Public Accounts (1962) Report of the Committee on the Simplification of the Public Accounts, Wellington: House of Representatives

Cook, D., C. Schousboe and D. Law (2011) Government and Economic Growth: does size matter?, Wellington: New Zealand Treasury

Easton, B. (2007) 'The current state of the public sector: an economist's view', paper presented at the annual public sector finance forum, Wellington, http://www.eastonbh.ac.nz/2007/09/the-current-state-ofthe-public-sector-an-economists-view-2/

Faricy, C. (2011) 'The politics of social policy in America: the causes and effects of indirect versus direct social spending', Journal of Politics, 73 (1), pp.74-83. doi: 10.1017/S0022381610000873

Financial Services Council (2013) The Tax Barrier to Retirement Prosperity in New Zealand, Wellington

Fiorramonti, L. (2013) Gross Domestic Product: the politics behind the world's most powerful number, London: Zed Books 
Forbes, G.W. (1931) Financial Statement: by the Right Hon. G.W. Forbes, Wellington: New Zealand Government

Gemmell, N. (1993) 'The public sector: definition and measurement issues', in N. Gemmell (ed.), The Growth of the Public Sector, Adlershot: Edward Elgar

Gemmell, N. and D. Gill (2016) 'The myth of the shrinking state? What does the data show about the size of the state in New Zealand, 1900-2015', Policy Quarterly, 12 (3), pp.3-10

Gibbons, M. (2000) 'Election programmes in New Zealand politics, 1911-1996', PhD thesis, University of Waikato

Gibbons, M. (2001) 'New Zealand government expenditure patterns between 1913 and 1944', paper presented at the New Zealand Political Studies Association, Palmerston North

Gleisner, B., M. Llewellyn-Fowler and F. McAlister (2011) Working Towards Higher Living Standards for New Zealanders, Wellington: New Zealand Treasury

Goldsmith, P. (2008) We Won, You Lost, Eat That! A political history of tax in New Zealand since 1840, Auckland: David Ling

Hofferbert, R.I. and I. Budge (1996) 'Patterns of post-war expenditure in ten democracies', in L. Imbeau (ed.), Comparing Government Activity, Basingstoke: Macmillan

Howard, C. (1997) The Hidden Welfare State: tax expenditures and social policy in the United States, Princeton: Princeton University Press

Howard, C. (2007) The Welfare State Nobody Knows, Princeton: Princeton University Press

Jones, M.A. (1980) The Australian Welfare State, Sydney: Allen and Unwin

King, A. (2014) 'Landlords say low taxes cap rents', Dominion Post, 3 July, retrieved from http://www.stuff.co.nz/business/money/10228984/ Landlords-say-low-taxes-cap-rents

McKinlay, P.J. (1983) 'Origin of Budget Table 2', AALR W5427 873, box 211, Archives New Zealand

New Zealand Planning Council (1979) Public Expenditure and its Financing, 1950-1979: a companion volume to the welfare state? Social policy in the 1980s, Wellington: New Zealand Planning Council

New Zealand Treasury (1935) Balance Sheets and Statements of Account of Various Government Departments for the Year 1935 (audited accounts), Wellington: New Zealand Government

New Zealand Treasury (1973) Budget 1973, Wellington: New Zealand Treasury

New Zealand Treasury (1984) 1984 Budget Part II: tables, Wellington: New Zealand Treasury

New Zealand Treasury (1986) 1986 Budget Part II: economic commentary and budget tables, Wellington: New Zealand Treasury

New Zealand Treasury (1994) Economic and Fiscal Outlook 1994, Wellington: New Zealand Treasury

New Zealand Treasury (2004) Long-term data series, retrieved 24 March 2013 from http://www.stats.govt.nz/browse_for_stats/economic indicators/nationalaccounts/long-term-data-series.aspx

New Zealand Treasury (2006) New Zealand's Long-Term Fiscal Position, Wellington: New Zealand Treasury
New Zealand Treasury (2008) 'Fiscal time series explanatory note', Wellington: New Zealand Treasury

New Zealand Treasury (2010) Treasury Report: potential of irrigation, Wellington: New Zealand Treasury

New Zealand Treasury (2014) '2014 tax expenditure statement', Wellington: New Zealand Treasury

New Zealand Treasury (2016) 'Data - fiscal time series historical fiscal indicators 1972-2014', retrieved 2 January 2016 from http://www. treasury.govt.nz/government/data

OECD (2010) Tax Expenditures in OECD Countries, Paris: OECD

OECD (2011) Government at a Glance 2011, Paris: OECD

OECD (2013) OECD Economic Surveys: New Zealand, Paris: OECD

Olson, M. (1982) The Rise and Decline of Nations: economic gro wth, stagflation and social rigidities, New Haven: Yale University Press

Preston, D. (1980) Government Accounting in New Zealand: an explanation of the accounting and financial system of the central government of New Zealand, Wellington: Government Printer

Preston, D. (2008) Retirement Income in New Zealand: the historical context, Wellington: Retirement Commission

Rea, D. (2009) 'Government expenditure and income in New Zealand: a brief overview', Policy Quarterly, 5 (3), 58-67

Rose, D. (2014) Trends in Public Revenue and Spending, 1948 to 2013, Paekakariki: Institute for Governance and Policy Studies

Rudd, C. (1991) 'The changing structure of public expenditure', in J. Boston, J. Martin, J. Pallot and P. Walsh (eds), Reshaping the State: New Zealand's bureaucratic revolution, Auckland: Oxford University Press

Shand, D. (1979) 'Measuring government expenditure and the budget', Public Sector Accounting, October, pp.350-4

Shuttleworth, K. (2013) 'Government backs out of carpark tax', New Zealand Herald, 18 March, retrieved from http://www.nzherald.co.nz/ business/news/article.cfm?c_id =3andobjectid $=10872016$

Statistics Department (1941) New Zealand Official Year-book, Wellington: Statistics Department

Statistics Department (1950) New Zealand Official Year-book, Wellington: Statistics Department

Statistics Department (1953) New Zealand Official Year-book, Wellington: Statistics Department

Statistics Department (1980) New Zealand Official Yearbook, Wellington: Statistics Department

Stebbing, A. and B. Spies-Butcher (2010) 'Universal welfare by "other means"? Social tax expenditures and the Australian dual welfare state', Journal of Social Policy, 39 (4), pp.585-606, doi: doi:10.1017/ S0047279410000267

Tan, D. (1981) 'Reconciliation Between the Budget and New Zealand System of National Accounts (NZSNA)', AALR W5427 873, box 211, Archives New Zealand

Thorns, D. and C. Sedwick (1997) Understanding Aotearoa/New Zealand: historical statistics, Palmerston North: Dunmore Press

Wanna, J., J. Kelly and J. Forster (2000) Managing Public Expenditure in Australia, Sydney: Allen and Unwin 